\title{
Identifikasi Model Curah Hujan Dengan Struktur Model Linier Dan Estimasi Parameter Dengan Algorithma Quadrad Terkecil
}

\author{
Ade Elbani \\ Kelompok Keahlian Teknik Kendali \\ Jurusan Teknik Elektro, Fakultas Teknik, Universitas Tanjungpura Pontianak \\ e-mail : ade.elbani@ee.untan.ac.id
}

\begin{abstract}
Curah hujan dari waktu kewaktu tidak lagi menunjukkan suatu kejadian yang linier, yakn imemiliki periode yang sangat tidak menentu. Hal ini terjadi juga ada hubungan dengan kondisi alam yang menyebabkan perubahan ekosistem, sehingga mengakibatkan proses penguapan maupun kondensasi uap terganggu. Untuk melakukan perkiraan terhadap cuaca yang akan datang, maka terlebih dahulu dilakukan Pemodelan. Untuk pemodelan system dilakukan secara penurunan matematika kan sangat sulit, dan banyak elemen yang terabaikan, terutama elemen nonlinier, sehingga hasil dari model tersebut, masih kurang begitu efektif guna diterapkan langsung dilapangan. Selain metoda tersebut, ada metoda pemodelan lain,yaitu metoda identifikasi. Metoda ini akan memodelkan sistem secara keseluruhan, baik elemen linier maupun nonlinier yang kesemuaitu dianggap menjadi satu kesatuan sistem yang terpadu (black box). Metoda ini akan menggunakan pasangan data masukan dan keluaran system secaranyata. Pada pemodelan sistem ini akan menggunakan struktur model linier akan merepresentasi sistem secara linier. Akan diambil data sampel curah hujan selama sepuluh tahun terakhir dari Stasiun BMKG Rahadi Oesman Ketapang, sebagai referensi proses pemodelan, yaitu dengan pendekatan struktur model nonlinier,yaitu pendekatan model Hammerstein, serta parameter estimai dengan menggunakan algorithma kuadrat terkecil (least square). Dari model yang diperoleh, akan diperoleh model parameter serta struktur model yang optimal, sehingga diperoleh model system yang baik, selanjutnya bisa dipergunakan untuk keperluan lain, misalnya untuk memperkirakan curah hujan yang akan dating.
\end{abstract}

Keywords- SistemIdentifikasi, black box, Model Linier, Algorithma least square.

\section{Pendahuluan}

Pada kenyataannya sistem-sistem yang ada merupakan keterpaduan unsur-unsur linier dan nonlinier ${ }^{[3]}$. Untuk pemodelan dengan penurunan matematis kesemua ini dilakukan dengan banyak berkisar pada daerah yang linier saja, sedangkan unsur nonlinier tidak banyak diperhatikan atau diabaikan. Oleh sebab itu hasil dari model yang diturunkan berdasarkan hukum fisika atau penurunan matematis, masih kurang begitu efektif guna diterapkan langsung dilapangan, namun demikian, adanya model dengan penurunan matematis setidaknya mempermudah untuk mengetahui tentang sifat atau karakter sistem tersebut.

Selain dengan metoda penurunan hukum-hukum fisika atau penurunan secara matematis, terdapat juga metoda lain guna melakukan pemodelan sistem, yaitu dengan menggunakan metoda identifikasi. Metoda ini akan memodelkan sistem secara keseluruhan, baik unsur (elemen) linier maupun nonlinier. Kesemua itu dianggap menjadi satu kesatuan sistem yang terpadu (black box). Proses pemodelan ini dilakukan atas dasar pasangan data masukan dan keluaran dari sistem yang akan dimodelkan ${ }^{[1]}$.

Pada pemodelan sistem ini akan digunakan struktur model linier, yang mana akan merepresentasi sistem secara linier, pada proses pemodelannya dianggap tidak terdapat gangguan dari sinyal atau data lain, selain pasangan data masukan dan keluaran dari sistem. Kriteria atau jenis model yang akan digunakan sangat berpengaruh pada hasil yang akan dicapai.

Pada penelitian ini akan dilakukan pemodelan sistem pembangkit daya, dengan pendekatan struktur model linier, serta estimasi parameter dengan menggunakan algoritma kuadrat terkecil (least square). Dari proses pemodelan yang akan dilakukan, diharapkan mendapatkan hasil yang optimal, sehingga diperoleh model yang baik. Selanjutnya model ini bisa dipergunakan untuk keperluan lain, misalnya untuk keperluan pengontrolan, keperluan analisis, sertakeperluansimulasi lainnya.

\section{Sistem Identifikasi}

Sistem identifikasi adalah merupakan metoda pemodelan yang berdasarkan pada data masukan dan keluaran sistem dinamis secara nyata, dimana dengan mengetahui data masukan dan keluarannya, akan diperoleh suatu model yang dapat merepresentasikan sistem tersebut. Namun demikian hasil yang dicapai tidaklah merupakan sesuatu yang dikatakan benar ataupun salah (secara kuantitatif), akan tetapi pernyataan yang lebih tepat adalah baik atau tidak baik (secara kualitatif). Untuk dapat mengatakan baik dan tidak baik, maka diperlukan kriteria tertentu yang merupakan landasannya. 


\subsection{Prosedur Identifikasi}

Pemodelan menggunakan metoda identifikasi dilakukan dengan cara menganalisa data masukan dan keluaran sistem dengan beberapa prosedur. Langkahlangkah atau prosedur identifikasi yang dilakukan adalah sebagai berikut ${ }^{[1]}$.

Melakukan pengujian dan mengambil data masukan serta data keluaran dari sistem dengan ekspriment, dalam hal ini data yang diambil harus dapat memberikan informasi yang cukup tentang prilaku sistem.

Memilih dan menentukan struktur model yang merupakan suatu set deskripsi kandidat sistem dimana model akan diperoleh; Kandidat model (himpunan model) diperoleh dengan menetapkan kumpulan model yang menjadi tempat untuk memilih model yang sesuai. Pada langkah ini sangat penting, dan merupakan langkah yang sulit, karena dibutuhkan pengetahuan apriori, intuisi rekayasa, serta wawasan dan sifat umum dari model.

Menentukan model terbaik dari kandidat model yang telah ditentukan pada prosedur diatas; Pada langkah ini dilakukan estimasi parameternya dengan algoritma identifikasi berdasarkan data masukan dan keluaran yang telah diperoleh.

Melakukan validasi terhadap model terbaik yang digunakan, pada langkah ini dilakukan pengujian terhadap kualitas model dengan mengamati performasi model tersebut. Jika model yang dipilih telah memuaskan, maka proses identifikasi dihentikan, namun sebaliknya jika masih belum memuaskan maka diulangi lagi prosedure ketiga diatas.

Dalam penulisan ini akan dilakukan dengan teknik parametrik, guna memperoleh parameter dari model secara langsung, dan teknik optimasi dilakukan dengan menggunakan algoritma least square.

\subsection{Struktur Model Linier}

Pada setiap sistem yang ada pasti memiliki karakter atau sifat yang berbeda, tergantung pada karakteristik alami maupun kondisi pada saat sekarang. Perubahan karakteristik yang disebabkan lelah struktur maupun pengaruh alami lainnya akan merubah suatu model dari sistem tersebut. Karakter tersebut terindikasi secara kwantitatif pada model matematik yang diperoleh. Secara umum model matematik dalam bentuk persamaan differensial direpresentasikan sebagai persamaan berikut $^{[3]}$,

$a_{n} \frac{d x_{o}^{n}}{d t^{n}}+a_{n-1} \frac{d x_{o}^{n-1}}{d t^{n-1}}+\cdots+a_{1} \frac{d x_{o}}{d t}+a_{o} x_{o}=b_{m} \frac{d x_{o}^{m}}{d t^{m}}+b_{m-1} \frac{d x_{o}^{m-1}}{d t^{m-1}}+\cdots+b_{1} \frac{d x_{o}}{d t}+b_{o} x_{o}$

Dimana :

$x_{i}=$ Data input

$x_{o}=$ Data output.

$a_{n}$ dan $a_{m}=$ Parameter model dari sistem,

$m$ dan $n=$ Orde sistem

Persamaan differensial diatas dirubah dalam bentuk persamaan laplace sebagai berikut. $\frac{x_{o}(s)}{x_{i}(s)}=\frac{b_{m} s^{m}+b_{m-1} s^{m-1}+\cdots+b_{1} s+b_{0}}{a_{n} s^{n}+a_{n-1} s^{n-1}+\cdots+a_{1} s+a_{0}}$

Dengan demikian hubungan masukan dan keluaran dari sistem dapat ditunjukkan dalam bentuk black box (kotak hitam) dibawah ini ${ }^{[3]}$,

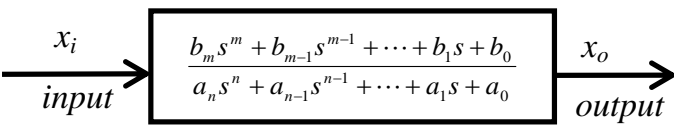

Dari fungsi transfer tersebut terdapat orde $m$ dan $n$, dimana $m$ terdapat pada jenis pembilang atau numerator dan $n$ pada penyebut atau denumerator. Orde dari sistem diindikasikan dengan jumlah $n$, sedangkan jumlah $m$ menunjukkan jenis atau type dari sistem tersebut, misalnya $m=2$ dan $n=1$ maka model tersebut mempunyai orde-2, type-1.

\subsection{Algorithma Kuadrat Terkecil}

Hubungan keluaran dan masukan model linier seperti pada persamaan umum di atas, dalam bentuk polinomial dapat dinyatakan sebagai persamaan berikut $^{[1,2]}$,

$$
A(q) x_{o}(t)=B(q) x_{i}(t-m)
$$

Dengan,

$m=$ waktu tunda masukan terhadap keluaran

$A$ dan $B$ adalah polinomial dalam operator tunda $q^{-1}$ dapat ditulis dalam bentuk

$$
\begin{aligned}
& A(q)=1+a_{1} q^{-1}+\cdots+a_{n} q^{-n} \\
& B(q)=1+b_{1} q^{-1}+\cdots+b_{m} q^{-m}
\end{aligned}
$$

dimana $m$ dan $n$ adalah orde polinomial.

Dengan demikian, akan didapat fungsi transfer (fungsi alih) persamaan diatas yaitu,

$$
G(q)=q^{-m} \frac{B(q)}{A(q)}
$$

Persamaan diatas dinyatakan dalam bentuk persamaan kontinyu berikut.

$$
a_{n} x_{i} s^{n}+a_{n-1} x_{i} s^{n-1}+\cdots+a_{1} x_{i} s+a_{0} x_{i}=b_{m} x_{o} s^{m}+b_{m-1} x_{o} s^{m-1}+\cdots+b_{1} x_{o} s+b_{0} x_{o}
$$

Untuk keperluan komputasi, persamaan kontinyu diatas dirubah dalam bentuk persamaan diskrit berikut.

$a_{n} x_{i}(t-n)+a_{n-1} x_{i}(t-n-1)+\cdots+a_{1} x_{i}(t-1)+a_{0} x_{i}(t)=$

$b_{m} x_{o}(t-m)+b_{m-1} x_{o}(t-m-1)+\cdots+b_{1} x_{o}(t-1)+b_{0} x_{o}(t)$

Dengan memisahkan ruas kiri kekanan sebagian unsur, didapat persamaan berikut,

$a_{0} x_{i}(t)=-a_{n} x_{i}(t-n)-a_{n-1} x_{i}(t-n-1)-\cdots-a_{1} x_{i}(t-1)+$

$b_{m} x_{o}(t-m)+b_{m-1} x_{o}(t-m-1)+\cdots+b_{1} x_{o}(t-1)+b_{0} x_{o}(t)$

Untuk mempermudah perhitungan, maka parameter $a_{o}$ dianggap satu (unity), dengan demikian persamaan diatas menjadi

$$
\begin{aligned}
& x_{i}(t)=-a_{n} x_{i}(t-n)-a_{n-1} x_{i}(t-n-1)-\cdots-a_{1} x_{i}(t-1)+ \\
& b_{m} x_{o}(t-m)+b_{m-1} x_{o}(t-m-1)+\cdots+b_{1} x_{o}(t-1)+b_{0} x_{o}(t)
\end{aligned}
$$


Persamaan diskrit tersebut dilakukan dengan waktu sampling $t$, dimana untuk sinyal masukan $x_{i}(t)$ adalah sinyal masukan pada saat sekarang, sedangkan untuk $x_{i}(t-1)$ adalah sinyal masukan pada waktu (step) sebelumnya (penundaan dalam satu satuan waktu), begitu juga dengan sinyal keluaran.

Persamaan diatas dibuat dalam bentuk matrik adalah sebagai berikut ${ }^{[4]}$.

$x_{i}(t)=\left[\begin{array}{lllllllll}-a_{n} & -a_{n-1} & \cdots & -a_{1} & +b_{m} & +b_{m-1} & \cdots & +b_{1} & +b_{0}\end{array}\right]\left[\begin{array}{c}x_{i}(t-n) \\ x_{i}(t-n-1) \\ \vdots \\ x_{i}(t-1) \\ x_{o}(t-m) \\ x_{o}(t-m-1) \\ \vdots \\ x_{o}(t-1) \\ x_{o}(t)\end{array}\right]$

Dimana,

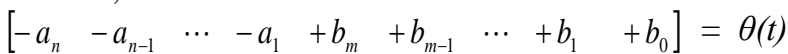

( $\theta(t)$ adalahVektor parameter )

$$
\left[\begin{array}{c}
x_{i}(t-n) \\
x_{i}(t-n-1) \\
\vdots \\
x_{i}(t-1) \\
x_{o}(t-m) \\
x_{o}(t-m-1) \\
\vdots \\
x_{o}(t-1) \\
x_{o}(t)
\end{array}\right]=\varphi(t)=\text { Vektor input output }
$$

Dengan penyederhanaan, persamaan diatas dapat dibuat menjadi

$$
x_{i}(t)=\theta(t) \cdot \varphi(t)
$$

Dimana $: x_{i}(t) \quad=$ Sinyal masukan sistem

$$
\begin{aligned}
& x_{o}(t)=\text { Sinyal keluaran sistem } \\
& \theta(t)=\text { Vector parameter } \\
& \varphi(t)=\text { Vektor input-output }
\end{aligned}
$$

Persamaan tersebut diatas disebut regresi linier dari sistem. Dengan mensubstitusi ruas kiri dan ruas kanan persamaan tersebut, maka diperoleh persamaan berikut.

$$
\theta(t)=\left(\varphi^{T}(t) \varphi(t)\right)^{-1} \varphi(t) x_{o}(t)
$$

Dimana persamaan tersebut adalah persamaan least square, merupakan algoritma optimasi yang akhirnya digunakan untuk mencari parameter-parameter sistem parameterik. Kesemua elemen dari persamaan tersebut adalah dalam bentuk matrik.

\subsection{Validasi Sistem}

Validasi sistem sangat penting dalam suatu sistem pemodelan, yang mana akan menentukan apakah suatu sistem tersebut baik atau tidak serta juga bisa untuk menentukan apakah suatu model bisa diterima ataupun tidak.
Untuk menentukan seberapa baiknya suatu sistem yang dihasilkan dari suatu proses identifikasi, maka dilakukan proses validasi terhadap data keluaran dari data masukan. Pada sistem identifikasi ini, ada beberapa metoda validasi yang bisa digunakan, misalnya Final Prediction Error (PFE),Loss Fuction, Akaike Information Criteria (AIC), dan sebagainya.

\subsubsection{Loss function dan Variansi ${ }^{[5]}$}

Dalam mengidentifikasi suatu sistem, kenaikan dari orde model akan menyebabkan penurunan pada variansi $\wedge 2$ $\hat{\sigma}^{2}$ dan loss function. Dengan asumsi bahwa loss function diperoleh dari suatu model kuadrat terkecil orde $\mathrm{n}$ dengan $\mathrm{p}$ parameter dan panjang data untuk proses identifikasi adalah $\mathrm{N}$, variansi dapat dinyatakan sebagai,

$\hat{\sigma}^{2}=\frac{2}{N} V_{N}\left(\theta_{N}\right)=\frac{1}{N} \sum_{i=1}^{N} \varepsilon_{i}^{2}\left(\theta_{N}\right)$ dengan $\theta_{N} \in R^{p}$

Variansi $=\frac{1}{N} \sum_{1}^{N} e_{i} e_{i}^{T}$ Loss Function $=\frac{1}{2} \sum_{1}^{N} e_{i} e_{i}^{T}$

\section{Data Sistem}

Data curahhujan yang hendakdigunakanadalah data kondisi curah hujan yang akan diambil dari BMKG Kabupaten Ketapang, dalam perioda waktu beberapa tahun, data tersebut akan diverifikasi menjadi pasangan data masukandan data keluaran.

Data masukan dalam hal ini adalah data curah hujan tahun 2002, dan data keluaran adalah data curah hujan tahun 2003.

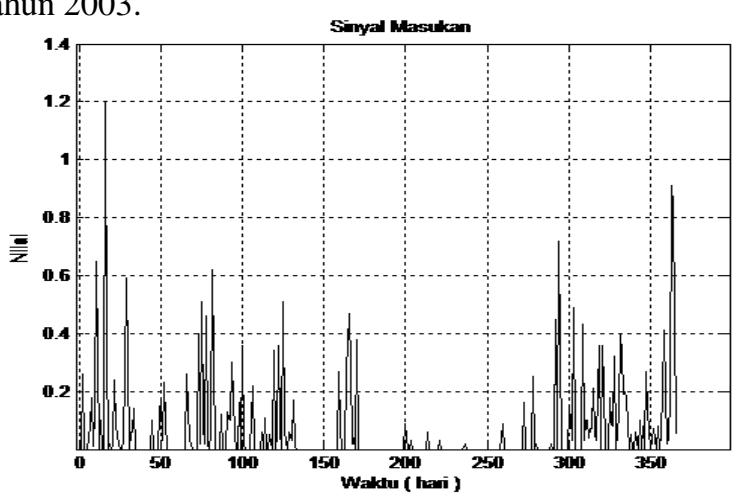

Sumber BMKG Kab. Ketapang tahun 2002

Gambar 1. Data Masukan

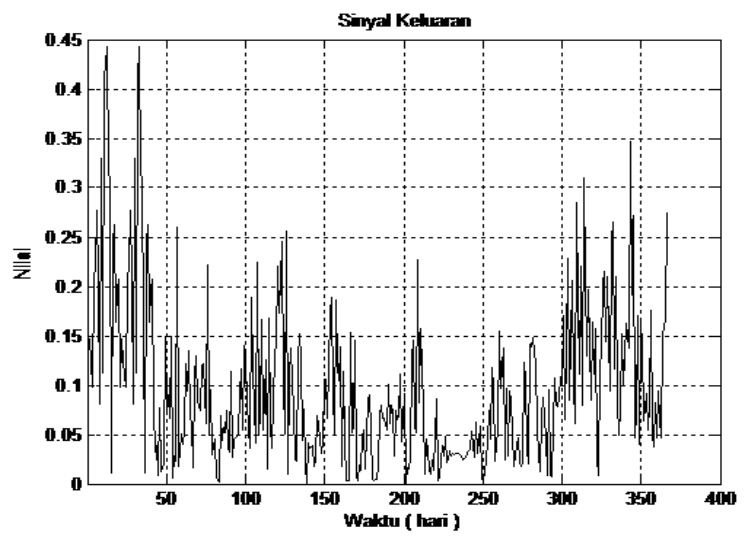

Sumber BMKG Kab. Ketapangtahun 2003

Gambar 2. Data Keluaran 


\section{Pemodelan Sistem.}

Proses identifikasi ini akan dilakukan dengan mencari orde dari sistem yang opimal, yaitu dengan metoda try-error, dimulai dengan orde yang paling rendah. Orde tersebut dikombinasi dan divariasi terhadap orde sistem dan typenya. Untuk orde sistem diindikasikan dengan bilangan denumerator tertinggi, dalam hal ini $\mathrm{n}_{\mathrm{a}}$ (atau pangkat tertinggi denumerator). Sedangkan type sistem adalah pangkat tertinggi dari numerator, yaitu $\mathrm{n}_{\mathrm{b}}$. kesemua ini akan dilakukan dengan mengkombinasi dan mencoba dari beberapa orde sistem dan typenya, sehingga akan didapat model yang baik berdasarkan pada sistem validasinya.

Untuk mendapatkan parameter sistem, digunakan algorithma least square, yang mana dalam setiap orde akan menghasilkan suatu model dengan bilangan parameter tertentu, sesuai dengan data masukan keluarannya. Pada proses identifikasi ini akan mencari model, yaitu model curah hujan khususnya dilokasi Ketapang.

Penentuan model Sistem, setiap step orde yang didapatdiplotterhadapnilaikriteriastatistik yang digunakan, uaitu pada penelitian ini akan digunakan kriteria Final Prediction Error (FPE) dan Loss-function $(L F)$, yang mana dari hasil ploating grafik dipilih nilai kriteria yang paling kecil, serta tingkat konvegensi system dari trend grafik tersebut.

\subsection{Identifikasi Sistem}

Identifikasi sistem model curah hujan ini akan menggunakan algoritma least square, guna mengestimasi parameter dari setiap model. Kriteria validasi yang digunakan adalah Final Prediction Error (FPE) yang hasil diperlihatkan pada Loss-function ( $L F)$, hasil estimasi diperlihatkan pada table 3.Jumlah pasangan data dalam hal ini adalah sebanyak 366 cacah data, yaitu data keluaran yang diimplementasikan dari data curah hujan harian selama satu tahun (thn 2003), serta data masukan yang diimplemen- tasikan dari data curah hujan harian selama satu tahun (thn 2002).

Untuk menentukan kandidat model pada proses identifikasi ini dilakukan dengan metoda uji coba (tryerror)daribeberapa kemungkinan ordemodel, yaitu dari orde model yang paling kecil $\left(\mathrm{n}_{\mathrm{a}}=\mathrm{n}_{\mathrm{b}}=1\right)$ serta variasi beberapa orde yang lebih tinggi. Dengan demikian akan terlihat indikasi kriteria (nilai loss funtion dan nilai $F P E$ ) terkecil serta memperlihatkan tingkat konvergenitas dari beberapa kandidatorde model tersebut.

Hasil dari penentuan kandidat model ini diperlihatkan pada tabel 3, dimana berdasarkan kriteria, yaitu nilai FPE (final Prediction Error) dan lossfunction, maka orde terkecil dan konvergen yang akan dipilih. Dari percobaan penentuan model ini, ditentukan struktur model denganorde $5\left(\mathrm{n}_{\mathrm{a}}=\mathrm{n}_{\mathrm{b}}=5\right)$ sebagai model yang memenuhikriteria, karena memiliki nilai kriteria loss function dan FPE relatif paling kecil dibanding kandidat lainnya, dan orde paling rendah serta konvergen yang diperlihatkan pada gambar 7 dan 8 .

\subsection{Estimasi Parameter Model}

Proses identifikasi sistem ini dilakukan dengan melakukanestimasi parameter menggu-nakan algorithma kuadrad terkecil (least square), sedangkanmetoda pemilihan orde sistem dilaku-kan dengan metoda tryerror (coba-coba), yaitu dengan memasukkannilai orde yang paling rendah, yaitu orde satu, dan seterusnya. Dari proses tersebut, semua hasil validasi sistem, secara visual (gambar 4),terlihat sinyal estimasi bisamengikuti sinyal referensi (sinyal keluaran),dan juga dengan uji statistik lainnya, yaitu diperlihatkan pada grafik Kriteria Statistik Crosscorelasi dan Autocorelasi (gambar 5 dan 6), dimana telah masuk pada ketentuan kriteria, dimana terdapat didalam batas garis yang diperbolehkan.

Dari proses identifikasi sistem curah hujan dengan mengunakan algorithma least square ini, diperoleh parameter-parameter estimasi kandidat model yang diperlihatkan pada tabel 1 dan Tabel 2 berikut,

Tabel 1. Parameter DenumerikSistem

\begin{tabular}{cccccccc}
\hline & \multirow{6}{c}{$\mathbf{n}_{\mathbf{a}}$} & $\mathbf{n}_{\mathbf{b}}$ & \multicolumn{6}{c}{ Parameter } \\
\cline { 3 - 8 } & & $\mathbf{a}_{\mathbf{0}}$ & $\mathbf{a}_{\mathbf{1}}$ & $\mathbf{a}_{\mathbf{2}}$ & $\mathbf{a}_{\mathbf{3}}$ & $\mathbf{a}_{\mathbf{4}}$ & $\mathbf{a}_{\mathbf{5}}$ \\
\hline 5 & 5 & -0.2822 & -0.227 & -0.09 & 0.1041 & -0.2149 & 0.0962 \\
\hline
\end{tabular}

Tabel 2.Parameter Numerik Sistem

\begin{tabular}{ccccccc}
\hline & & \multicolumn{5}{c}{ Parameter } \\
\cline { 3 - 7 } $\mathbf{n}_{\mathbf{a}}$ & $\mathbf{n}_{\mathbf{b}}$ & $\mathbf{b}_{\mathbf{1}}$ & $\mathbf{b}_{\mathbf{2}}$ & $\mathbf{b}_{\mathbf{3}}$ & $\mathbf{b}_{\mathbf{4}}$ & $\mathbf{b}_{\mathbf{5}}$ \\
\hline 5 & 5 & 0.0359 & 0.0539 & 0.0544 & -0.0319 & 0.0191 \\
\hline
\end{tabular}

\subsection{Validasi Sistem}

Setiap kandidat model, akan menghasilkan sinyal keluaran estimasi dengan sinyal masukan yang sama. Sinyal keluaran estimasi ini tidak selalu sama dengan sinyal keluaran yang sebenarnya, yakni selalu ada selisih (error). Selisih sinyal ini yang akan menentukan kriteria dari model yang akan dipilih sebagai model sistem.

Pada penelitian ini, akan menggunakan kriteria statistik berupa loss function dan Final Prediction Error $(F P E)$, karena dalam mengidentifikasi suatu sistem, kenaikan dari orde model akan menyebabkan penurunan pada nilai Final Prediction Error (FPE) maupunloss function. Akhirnya dengan melihat nilai-nilai dari kriteria tersebut serta membandingkan dengan yang lainnya, maka akan ditentukan model yang dipilih dari kandidat-kandidat model lainnya.

Berdasarkan persamaan-persamaan di atas, diperoleh hasil validasi yang diperlihatkan pada tabel 2. Hasil validasi sistem akan menjukkan bahwa sistem dengan orde $5\left(\mathrm{n}_{\mathrm{a}}=\mathrm{n}_{\mathrm{b}}=5\right)$ sebagai model yang akan dipilih. 


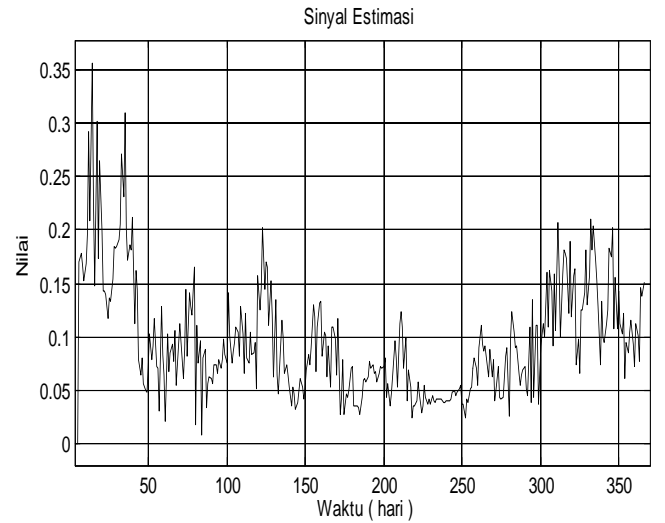

Gambar 3. Sinyal Estimasi

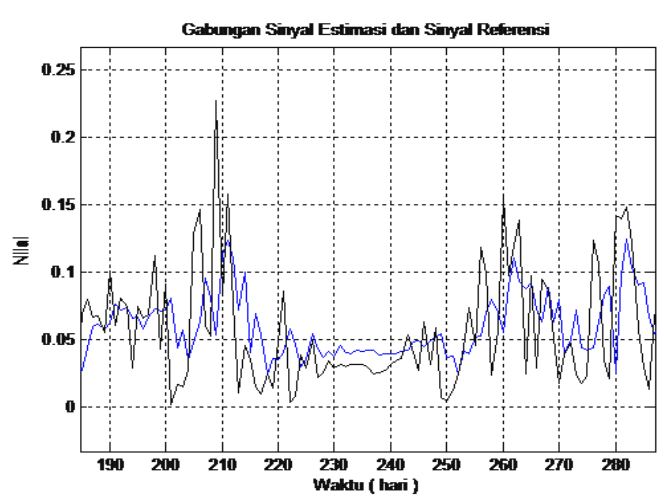

Gambar 4. Gabungan Sinyal Estimasi dan Referensi

Tabel3.ValidasiSistem

\begin{tabular}{|c|c|c|c|c|}
\hline \multirow{2}{*}{$\begin{array}{l}\text { Step } \\
\text { Orde }\end{array}$} & \multirow[b]{2}{*}{$\mathrm{Na}$} & \multirow[b]{2}{*}{$\mathbf{N b}$} & \multicolumn{2}{|c|}{ Validasi } \\
\hline & & & Lost Function & FPE \\
\hline 1 & 1 & 0 & 0.9725 & 0.0053 \\
\hline 2 & 1 & 1 & 0.9159 & 0.0050 \\
\hline 3 & 2 & 0 & 0.8813 & 0.0048 \\
\hline 4 & 2 & 1 & 0.8230 & 0.0045 \\
\hline 5 & 2 & 2 & 0.8195 & 0.0045 \\
\hline 6 & 3 & 0 & 0.8446 & 0.0047 \\
\hline 7 & 3 & 1 & 0.8024 & 0.0044 \\
\hline 8 & 3 & 2 & 0.8010 & 0.0044 \\
\hline 9 & 3 & 3 & 0.7799 & 0.0043 \\
\hline 10 & 4 & 0 & 0.8582 & 0.0047 \\
\hline 11 & 4 & 1 & 0.8138 & 0.0045 \\
\hline 12 & 4 & 2 & 0.8126 & 0.0045 \\
\hline 13 & 4 & 3 & 0.7924 & 0.0044 \\
\hline 14 & 4 & 4 & 0.7876 & 0.0044 \\
\hline 15 & 5 & 0 & 0.8263 & 0.0046 \\
\hline 16 & 5 & 1 & 0.7957 & 0.0044 \\
\hline 17 & 5 & 2 & 0.7943 & 0.0044 \\
\hline 18 & 5 & 3 & 0.7829 & 0.0043 \\
\hline 19 & 5 & 4 & 0.7754 & 0.0043 \\
\hline 20 & 5 & 5 & 0.7678 & 0.0043 \\
\hline 21 & 6 & 0 & 0.8575 & 0.0048 \\
\hline 22 & 6 & 1 & 0.8260 & 0.0046 \\
\hline 23 & 6 & 2 & 0.8246 & 0.0046 \\
\hline 24 & 6 & 3 & 0.8129 & 0.0045 \\
\hline 25 & 6 & 4 & 0.8071 & 0.0045 \\
\hline 26 & 6 & 5 & 0.8048 & 0.0045 \\
\hline 27 & 6 & 6 & 0.8021 & 0.0045 \\
\hline 28 & 7 & 7 & 0.8222 & 0.0046 \\
\hline 29 & 8 & 8 & 0.8176 & 0.0046 \\
\hline 30 & 9 & 9 & 0.8315 & 0.0047 \\
\hline 31 & 10 & 10 & 0.8286 & 0.0047 \\
\hline
\end{tabular}

Hasil Proses Identifikasi dan Validasi Sistem

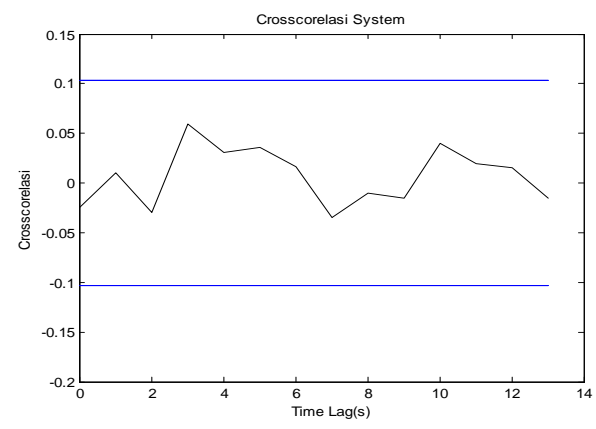

Gambar 5. Kriteria Statistik Crosscorelasi

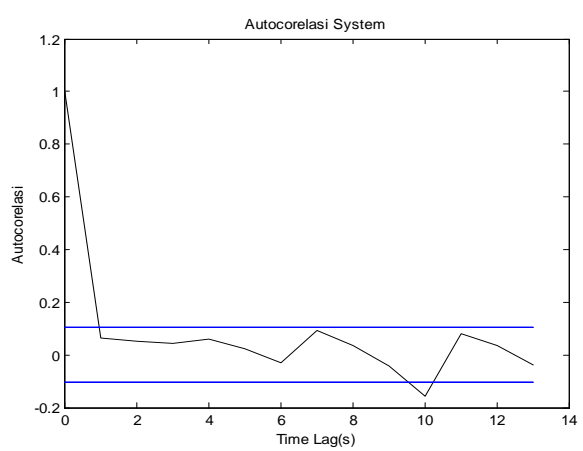

Gambar 6. Kriteria Statistik Autocorelasi

\section{Penentuan Model Sistem}

Untuk menentukan model sistem (curahhujan)ini, dilakukan dengan melihat kecenderungan pada setiap step orde yang diplotter hadap nilai kriteriastatistik yang digunakan (FPE dan loss-function), yang mana dari hasil ploating grafik tersebut dipilih nilaikriteria yang paling kecil, serta tingkat konvegensi dari system dari trend grafik.

Diperlihatkan pada gambar 7 dan 8 , bahwa model yang dipilih adalah model dengan step orde 5, atau model tersebut mempunyai orde lima, dimana $\left(n_{a}=n_{b}=5\right)$, diperlihatkan pada tabel 3 yang merupakan hasil validasi. Dari grafik sistem juga terlihat mengarah pada tingkat yang konvergen, yakni nilai orde semakin besar, trend grafik tidak menunjukkan arah yang negatip (kebawah). Hal ini menunjukkan bahwa orde yang dipilih adalah orde 5 merupakan orde yang optimal sebagai orde model.

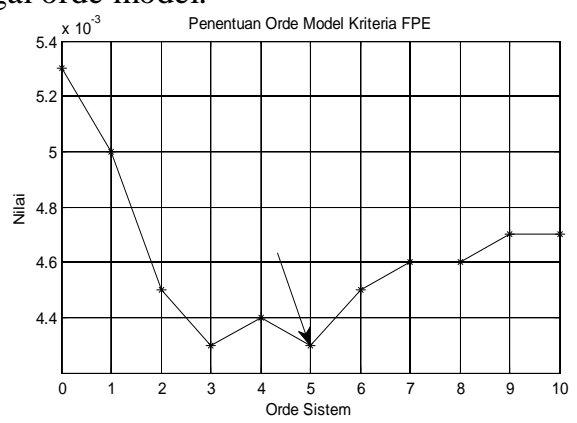

Gambar 7. Penentuan Model Berdasarkan Kriteria FPE 


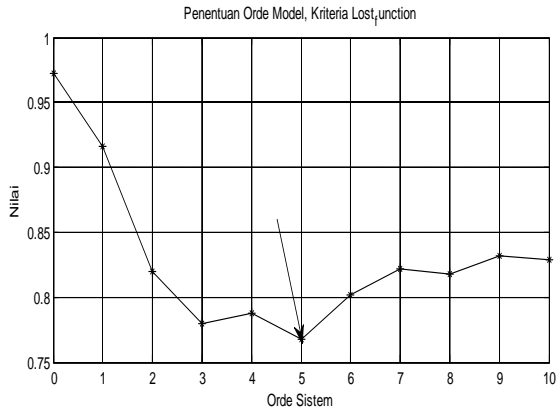

Gambar 8. Penentuan Model Berdasarkan Kriteria Lossfunction

\section{Hasil dan Analisis}

Secara analisa visual yang diperlihatkan pada gambar 3 menunjukkan bahwa visualisasi sinyal keluaran model estimasi dan sinyal keluaran model referensi hampir sama, seperti yang diperlihatkan pada gambat 4, yaitu sinyal keluaran estimasi mampu mengikuti sinyal keluaran referensi.

Dengan melihat trend grafik pada gambar 4 di atas, maka bisa disimpulkan bahwa model estimasi hampir sama dengan model referensi (sebenarnya). Secara kuantitatif dengan uji statistik yang diperlihatkan pada tabel 3, yaitu nilai Loss function dan nilai FPE relatif kecil (0.7678dan0.0043)terhadap model lainnya.

Untuk kriteria statistik baik kriteria correlaasi dan autocorelasi, terlihat seperti pada gambar 5 dan 6 , keduanya telah terpenuhi dengan terlihat grafik berada pada daerah fisibel atau terletak di dalam garis kriteria.

Dalam hal ini mengindikasikan bahwa kandidat model ini bisa dipilih sebagai model dari system curah hujan. Pada system identifikasi dengan uji statistic terhadap error tersebut menunjukkan bahwa semakin kecil harga FPE dan loss function tersebut, maka sistem akan semakin baik. Dengan demikian struktrur model tersebut sudah memenuhi kriteria validasi. Kesalahan (error) yang kecil antara sinyal keluaran nyata (yang sebenarnya) hampir sama (mendekati) hasil estimasi. Hal ini menunjukkan bahwa model yang sebenarnya akan mendekati model estimasi.

Pada sistem validasi modelcurah hujan ini, jika dilihat secara kuantitatif, harga FPE dan loss-funtion yang diperoleh sesungguhnya masih relatif besar. Hal ini menunjukkan selisih antara sinyal referensi dan estimasi juga masih dirasa besar, yang berarti sebenarnya model juga masih tidak begitu baik. Namun untuk menentukan model dari sistem, nilai ini relatif kecil dari yang lainnya, artinya model ini adalah yang terpilih sebagai model sitem curah hujan.

Hasil identifikasi pada sistemmodel sitem curah hujaninitelahmenghasilkansistemdenganorde5, yakni nilai $\mathrm{n}_{\mathrm{a}}$ dan $\mathrm{n}_{\mathrm{b}}$ sama. Jikadilihat secara ideal, keseluruhan sistem model sitem curah hujan adalah memiliki orde5, yaitu nilai orde numerator dan denumerator sama dengan lima.

Hasil estimasi parameter dengan menggunakan algorithma least square, serta pemilihan orde dengan uji statistik tersebut, maka diperoleh orde dan nilai parameter dari sistem model sitem curah hujan. Dengan memasukkan orde dan nilai-nilai tersebut, maka model dari sistem curah hujan dalam bentuk fungsi transfer adalah :

$G(s)=\frac{-0,0359 s^{4}+0,0539 s^{3}+0,0544 s^{2}-0,0319 s+0,0191}{-0,2822 s^{5}-0,227 s^{4}-0,09 s^{3}+0,1041 s^{2}-0,2149 s+0,0962+1}$

Pada persamaan model diatas, menunjukkan bahwa sistem model sitem curah hujan adalah sistem yang memiliki orde 5 dan type 5 .

Pada keseluruhan sistem dalam proses identifikasi ini sudah bisa diterima, karena prosedure dan program yang dilakukan berjalan dengan baik, serta perbandingan dari beberapa kandidat model juga baik. Namun agar lebih baik dan bisa digunakan langsung untuk keperluan analisis di lapangan, maka pasangan-pasangan data atau sistem pengambilan data lebih sangat diperhatikan, baik teknik maupun infra struktur yang ada, berupa peralatan atau alat-alat ukur. Secara keseluruhan dari sistem model sitem curah hujan ini, agar nilai validasi dari model baik atau harga FPE relatif kecil, maka pasangan data masukan dan keluaran sistem harus dilakukan atau diambil lebih teliti (accurate). Dalam hal ini tentu dengan peralatan atau alat-alat ukur yang langsung mengkonversi kan secara otomatis dalam bentuk digital.

\section{Kesimpulan}

Dari keseluruhan penulisan dan penelitian proses identifikasi sistem curah hujan ini disimpulkan sebagai berikut.

1. Pada penulisan sistem yang diidentifikasi, adalah system orde lima (5) dan type lima (5), dengan fungsi transfer :

$G(s)=\frac{-0,0359 s^{4}+0,0539 s^{3}+0,0544 s^{2}-0,0319 s+0,0191}{-0,2822 s^{5}-0,227 s^{4}-0,09 s^{3}+0,1041 s^{2}-0,2149 s+0,0962+1}$

2. Pada proses identifikasi sistem, hasil yang diperoleh sudah bisa diterima, secara analisa visual, trend sinyal estimasi sudah bisa mengkuti trend sinyal referensi. Namun demikian, model-model sistem yang diperoleh belumlah begitu baik, terlihat pada analisa kuantitatif yang berupa nilai-nilai criteria validasi(loss-fuctiondanFPE)masih relative besar.

3. Data curah hujan diperoleh dari BMKG Kabupaten Ketapang, namun demikian dari data yang diperoleh, masih terjadi ralat sistematik, hal ini terindikasi pada criteria validasi yang relative besar. 


\section{Referensi}

1. R. Haber and L. Kevieczky, 1999, Nonlinier System Identification Inpput-Output Modeling Approach, volume 1: Nonlinier System Parameter Identification.

2. R. Haber and L. Kevieczky, 1999, "Nonlinier System Identification Inpput-Output Modeling Approach", volume 2: Nonlinier System Parameter Identification

3. Rolf, Johansson; Sistem Modelling and Identification, Printice Hall Inc, Englewood Cliffs, 1993.

4. Landau, ID, "System indentification and Control design", Printice Hall Inc, Englewood Cliffs, 1990.

5. R. Haber, H. Unbehauen, 1990, Structure Identification of nonlinier Dynamic System - A Survey on Input/output Aproaches, Automatica, Vol. 26, No. 4, pp.651-677.

\section{Biografi}

Ade Elbani, was born in Sanggau, Indonesia, on May 22, 1963. He received the B. Eng from Gadjah mada University, Yogyakarta, Indonesia, 1992. M. Eng from Bandung Institute of Technology (ITB), Bandung, Indonesia, 2003. Since 1995 he has been a academic staff of engineering faculty at Electrical Engineering Department, Tanjungpura University. His current research interests modelling and control. 